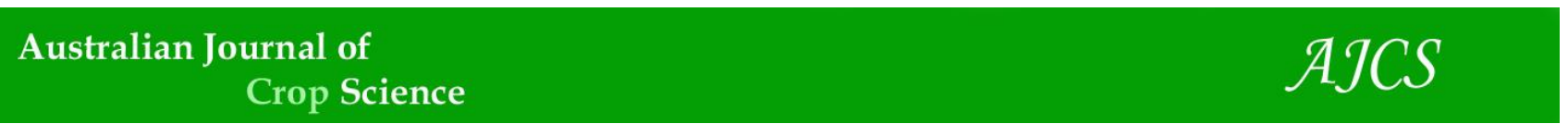

AJCS 14(07):1195-1201 (2020)

ISSN:1835-2707

doi: 10.21475/ajcs.20.14.07.p2731

\title{
Associations between microorganism and maize plant to remedy mercury- contaminated soil
}

\author{
Letícia Fernanda Lavezzo ${ }^{1,}{ }^{,}$, Denise de Lima Dias Delarica ${ }^{1}$, Anne Hélène Fostier ${ }^{2}$, Everlon Cid Rigobelo ${ }^{3}$, \\ Saveetha Kandasamy ${ }^{4}$, George Lazarovits ${ }^{2}$, Camila Chioda de Almeida ${ }^{3}$, Danilo Olandino Souza ${ }^{1}$, \\ Wanderley José de Melo ${ }^{1}$
}

\author{
${ }^{1}$ Department of Soil, São Paulo State University, Jaboticabal, SP, Brazil \\ ${ }^{2}$ Chemistry Institute, State University of Campinas, Campinas, SP, Brazil \\ ${ }^{3}$ Department of Microbiology, São Paulo State University, Jaboticabal, SP, Brazil \\ ${ }^{4}$ A\&L Biologicals Agroecology Research Services Center 2136 Jetstream Road London, ON N5V3P5
}

*Corresponding authors: leticialavezzo.unesp@hotmail.com

Abstract

\begin{abstract}
Mercury $(\mathrm{Hg})$ is one of the most toxic metals and is not essential for any organism. In this study, the potential of maize plants in association with bacteria to treat oxisol contaminated with $\mathrm{Hg}$ (II) was evaluated. The experiment was conducted in a controlled environment, and pots with $2 \mathrm{~kg}$ of oxisol were contaminated with $\mathrm{HgCl}_{2}$ solution at a dose of $36 \mathrm{mg} \mathrm{kg}^{-1}$ of $\mathrm{Hg}$ in a $7 \times 4$ factorial scheme: control (soil without $\mathrm{Hg}(\mathrm{II})$ and microorganisms), $\mathrm{T} 2=$ (soil with $\mathrm{Hg}(\mathrm{II})$ and without microorganisms), and $\mathrm{T} 3=$ soil with $\mathrm{Hg}(\mathrm{II})$ + Enterobacter cloacae, $\mathrm{T} 4=\mathrm{Hg}(\mathrm{II})+$ Bacillus subtilis, $\mathrm{T} 5=\mathrm{Hg}(\mathrm{II})+$ Enterobacter sp., $\mathrm{T} 6=\mathrm{Hg}(\mathrm{II})+$ Staphylococcus epidermidis, and T7= $\mathrm{Hg}(\mathrm{II})+$ Bacillus sp. Total $\mathrm{Hg}$ quantification was performed by atomic absorption spectrophotometry. At the end of the experiment, the soil pH was significantly lower ( 0.3 to $0.4 \mathrm{pH}$ unit) in the $\mathrm{T} 2$ (no inoculation), Enterobacter cloacae, Enterobacter sp. and Bacillus sp. treatments. Neither contamination of soil with $\mathrm{Hg}$ nor plant associations with bacteria led to differences in the root dry mass of maize plants. Maize plants associated with Staphylococcus epidermidis and Bacillus sp. bacteria had lower shoot biomass (71 and $50 \%$ ) compared to the treatment 2. The best remedial effect was observed with the association of maize plants with Bacillus sp., which recovered $19.67 \%$ of $\mathrm{Hg}(\mathrm{II})$ in the soil when compared to control and treatment 2 and treatment with $B$. subtilis. The recommendation is the use of $B$. subtilis to decrease the toxicity caused by $\mathrm{Hg}(\mathrm{II})$.
\end{abstract}

Keywords: Heavy metals; Phytoremediation; Bioremediation; Bacteria.

Introduction

Mercury $(\mathrm{Hg})$ is naturally found in igneous and sedimentary rocks (Adriano, 2001) and is often used in mining for the manufacture of lamps and batteries, in chlorine production, in dentistry, in the production of pharmaceuticals, pesticides, and insecticides and even in the manufacture of inks (Kabata-PendiasandMukherjee, 2007; Liet al., 2009).

$\mathrm{Hg}$ can be found in the oxidation states $\mathrm{Hg}^{0}$ (elemental $\mathrm{Hg}$ ), $\mathrm{Hg}(\mathrm{I})$ (mercurous) and $\mathrm{Hg}(\mathrm{II})$ (mercuric). In the atmosphere, $\mathrm{Hg}^{0}$ is predominant, while in soil, water and sediments, most $\mathrm{Hg}$ is in the form of inorganic salts of $\mathrm{Hg}(\mathrm{II})$, and in the biota, most $\mathrm{Hg}$ in the organic form of methylmercury $\left(\mathrm{CH}_{3} \mathrm{Hg}^{+}\right)$ (Adriano, 2001; Beckers and Rinklebe, 2017).

In the environment, $\mathrm{Hg}$ cannot be eliminated; however, it can undergo transformations from the most toxic forms, which are $\mathrm{Hg}^{2+}, \mathrm{CH}_{3} \mathrm{Hg}^{+}$and dimethylmercury, to less toxic forms such as $\mathrm{Hg}^{0}$ and $\mathrm{HgS}$ (Wagner-Döbler, 2013).

No organism uses $\mathrm{Hg}$ in its biosynthesis, and its presence in the environment has become a global concern due to its volatility, permanence in the environment and toxicity (Wanget al., 2003; Pacynaet al., 2016; Sundsethet al., 2017). For this reason, $\mathrm{Hg}$ was ranked by the Agency for Toxic
Substances and Disease Registry as the third most dangerous substance, only behind arsenic and lead (ATSDR, 2016).

Several regions of Brazil, mainly in the state of Minas Gerais, are contaminated with $\mathrm{Hg}$ due to gold mining activity (Windmöller et al., 2015). In the Amazon region, it is estimated that 15 years of mining have caused contamination with approximately 4,000 $\mathrm{t}$ of $\mathrm{Hg}$ (Lacerda, 2003; Bastos et al., 2006).

In the period from 2010 to 2013 , Brazil emitted $39,214,00$ $\mathrm{kg}$ of $\mathrm{Hg}$ to the environment, most of it from gold mining $(22,500 \mathrm{~kg})$ (UNEP, 2018). The amalgamation process is responsible for 55 to $65 \%$ of $\mathrm{Hg}$ emissions into the atmosphere, and the remainder of the metal is directly released into water resources and soil (Bastos and Lacerda, 2004). Currently, industries apply techniques for the remediation of soil contaminated with $\mathrm{Hg}$, which include vitrification (metal immobilization in a glass matrix), heat treatment (reduction of $\mathrm{Hg}(\mathrm{II})$ to $\mathrm{Hg}^{0}$ ), physicochemical extraction of metal from the soil (decrease in bioavailability) and encapsulation of reactive forms (decreased mobility) (Mahbubet al., 2017). However, these measures are costly. 
Therefore, less costly strategies for the remediation of contaminated areas, such as phytoremediation, have aroused worldwide attention for the recovery of soils and water resources. Plants can act as phytoextractors, phytostabilizers, and phytovolatilizers and act on phytodegradation, rhizodegradation and rhizofiltration (Tangahuet al., 2011). In addition, they indirectly contribute to phytoremediation by supporting symbiotic microorganisms that live in roots and are responsible for the detoxification of contaminants (Kumaret al., 2017).

Several studies have demonstrated the potential of plants to accumulate $\mathrm{Hg}$ in their biomass (Xunet al., 2017; Qianet al., 2018) along with a tendency for $\mathrm{Hg}$ to accumulate in higher proportions in roots than in shoots (Pedron et al., 2013, Chauhan and Mathu, 2018; Debeljak et al., 2018; Cabrita et al., 2019).

Concomitant to phytoremediation, bioremediation is a promising technique that uses microorganisms such as fungi, bacteria and yeasts (Naguibet al., 2018) that are resistant to heavy metals and other contaminants and transforms them into less toxic and less mobile forms in the environment (Dixit et al., 2015).

Microorganisms have different resistance mechanisms and strategies to bioaccumulate, biomineralize, biotransform, bioleach and adsorb contaminants from the environment. Bioremediation is successful in using appropriate microorganisms for each contaminant and in understanding interactions between microorganisms and the environment (Dixit et al., 2015).

Satisfactory results for the remediation of contaminated soils can be obtained from the association between bacteria and plants. Maize (Zea mays L.) is easily cultivated, has a high degree of mycorrhization and was evaluated as a possible $\mathrm{Hg}$ phytoremediation agent, especially when associated with microorganisms (Kodreet al., 2017; Debeljaket al., 2018). However, knowledge of the interactions between plants and microorganisms to phytoremediate $\mathrm{Hg}$ in oxisol is still incipient.

The aim of this study was to evaluate the remediation potential of maize plants associated with bacteria in soils contaminated with $\mathrm{Hg}$ (II) at concentrations higher than the maximum content of this chemical legally allowed in soils destined for agricultural use.

\section{Results and discussion}

Regarding soil $\mathrm{pH}$, there was no difference among treatments in the same evaluation period. However, the final $\mathrm{pH}$ was significantly lower ( 0.3 to $0.4 \mathrm{pH}$ unit) than the initial $\mathrm{pH}$ in the control and in treatments that received Enterobacter cloacae, Enterobacter sp. and Bacillus sp.

\section{Influence of the cultivation conditions on maize growth variables}

Soil contamination with $\mathrm{Hg}$ (II) and the presence of microorganisms led to differences in the shoot dry mass (PA) of maize plants (Fig 1). The shoot dry mass of the treatment 2 was higher than that of treatments with S. epidermidis and Bacillus sp. The growth of maize roots in soil contaminated with $\mathrm{Hg}$ and inoculated with bacteria was homogeneous in all treatments, with production of approximately $8 \mathrm{~g} \mathrm{~kg}^{-1}$. Influence of the cultivation conditions on $\mathrm{Hg}$ (II) content in the different compartments (soil, roots, and shoots).
After 44 days of soil contamination, associations between maize plants and bacteria did not show any differences among treatments; however, in general, there was a $56 \%$ reduction in soil $\mathrm{Hg}$ content (Fig 2). The concentration of $\mathrm{Hg}$ in the roots of maize plants associated with bacteria varied between 583.30 and $763.10 \mathrm{mg} \mathrm{kg}^{-1}$ and was always higher than the concentration found in the positive control $(0.99$ $\mathrm{mg} \mathrm{kg}^{-1}$ ) (Fig 2). Plants associated with Bacillus sp. showed $41 \%$ greater $\mathrm{Hg}$ accumulation in roots compared to the treatment 2. Regarding shoot phytomass, $\mathrm{Hg}$ concentrations varied between 0.17 and $8.67 \mathrm{mg} \mathrm{kg}$. Treatments associated with Enterobacter cloacae and Bacillus sp. presented an effective increase in shoot $\mathrm{Hg}$ accumulation by 306 and $142 \%$, respectively, compared to the treatment 2 .

Remediation efficiency

In the control (no inoculated), most $\mathrm{Hg}$ (92\%) initially present in soil $\left(0.3 \mathrm{mg} \mathrm{kg}^{-1}\right)$ was removed by the end of the experiment, but only a small part $(0.13 \%)$ was removed by plants (Table 3).

In contaminated soils, $\mathrm{Hg}$ removal ranged from 45.67 to $50.46 \%$, and no difference was observed among treatments. Nevertheless, only 5.91 to $9.34 \%$ of $\mathrm{Hg}$ initially present in contaminated soil was accumulated in plants, which accounted for 11.61 to $19.67 \%$ of $\mathrm{Hg}$ removed from the soil. When compared to the control, only cultivation in association with Bacillus sp. showed better efficiency in bioaccumulating $\mathrm{Hg}$ and therefore removing $\mathrm{Hg}$ from the soil. This treatment was able to remove $42.74 \%$ more $\mathrm{Hg}$ than the treatment 2 and $69.42 \%$ more $\mathrm{Hg}$ than the treatment with Bacillus subtilis.

The Hg content in the soil did not show a high correlation ( $p$ $<0.01$ ) with the root $\mathrm{Hg}$ content and an average correlation ( $p<0.05$ ) with total shoot $\mathrm{Hg}$ content. On the other hand, the $\mathrm{Hg}$ contents in the root and shoot phytomass showed an average correlation with each other. The other correlation values were low and not significant (Table 3 ).

$\mathrm{pH}$ and soil organic matter content (SOM) are the most important factors that directly affect the availability of heavy metals in the environment. $\mathrm{Hg}$ (II) has a higher affinity for SOM and its sulfur compounds than for inorganic complexes (Adriano, 2001; Zenget et al., 2011; Letermeand Jacques, 2015).

In general, higher $\mathrm{pH}$ and CTC values in soil directly favor the available negative charge sites and consequently increase the soil $\mathrm{Hg}$ adsorption (Soares et al., 2015). For this reason, liming was not performed in order to favor $\mathrm{Hg}$ availability.

The metal bioavailability in soil tends to be low and to accumulate in roots, as the endoderm acts as a barrier, decreasing $\mathrm{Hg}$ absorption by plants. As a defense mechanism, less $\mathrm{Hg}$ is translocated to the xylem, and the metal is accumulated in roots (Adriano, 2001; Debeljak et al., 2013). In our study, this finding was confirmed, as greater accumulation of the metal in roots than in the shoot phytomass was observed (Fig 2), corroborating the results obtained by Debeljak et al. (2013). The accumulation in maize roots grown in $\mathrm{Hg}$-contaminated soil can also be enhanced with the association of arbuscular mycorrhizae (Debeljaket al., 2018).

The chemical speciation of $\mathrm{Hg}$, as well as the vegetal species used in phytoremediation, has a direct influence on its translocation (Adriano, 2001). The content translocated by maize plants tends to accumulate more in the leaves and 
Table 1. Mean total mercury content in different treatments.

\begin{tabular}{|c|c|c|c|c|c|}
\hline Treatments & $\begin{array}{l}\text { Hg in soil } \\
\text { Beginning (mmSi) }\end{array}$ & $\begin{array}{l}\text { Hg in soil } \\
\text { Final (mmSf) }\end{array}$ & $\begin{array}{l}\mathrm{Hg} \\
(\mathrm{mmR})\end{array}$ & $\begin{array}{l}\text { Hg shoots } \\
\text { (mmPA) }\end{array}$ & $\begin{array}{l}\text { Total } \mathrm{Hg} \text { at the end of } \mathrm{Ti} \\
(\mathrm{mmSf}+\mathrm{mmR}+\mathrm{mmPA})\end{array}$ \\
\hline & \multicolumn{2}{|l|}{$---\mathrm{mg} \mathrm{kg}^{-1} \mathrm{Hg} \times 2 \mathrm{~kg}---$} & \multicolumn{2}{|c|}{$-\mathrm{mg} \mathrm{kg}^{-1} \mathrm{Hg} \times$ dry mass- } & ---mg kg ${ }^{-1}---$ \\
\hline Positive control & 11.12 & 0.60 & 0.007 & 0.003 & 0.61 \\
\hline Negative control & 74.86 & 40.35 & 4.57 & 0.068 & 44.99 \\
\hline Enterobacter cloacae & 74.86 & 40.68 & 5.15 & 0.25 & 46.1 \\
\hline Bacillus subtilis & 74.86 & 37.1 & 4.29 & 0.13 & 41.51 \\
\hline Enterobacter sp. & 74.86 & 38.64 & 5.66 & 0.046 & 44.09 \\
\hline Staphylococcus epidermidis & 74.86 & 40.18 & 4.94 & 0.030 & 45.14 \\
\hline Bacillus sp. & 74.86 & 39.28 & 6.84 & 0.152 & 46.28 \\
\hline
\end{tabular}

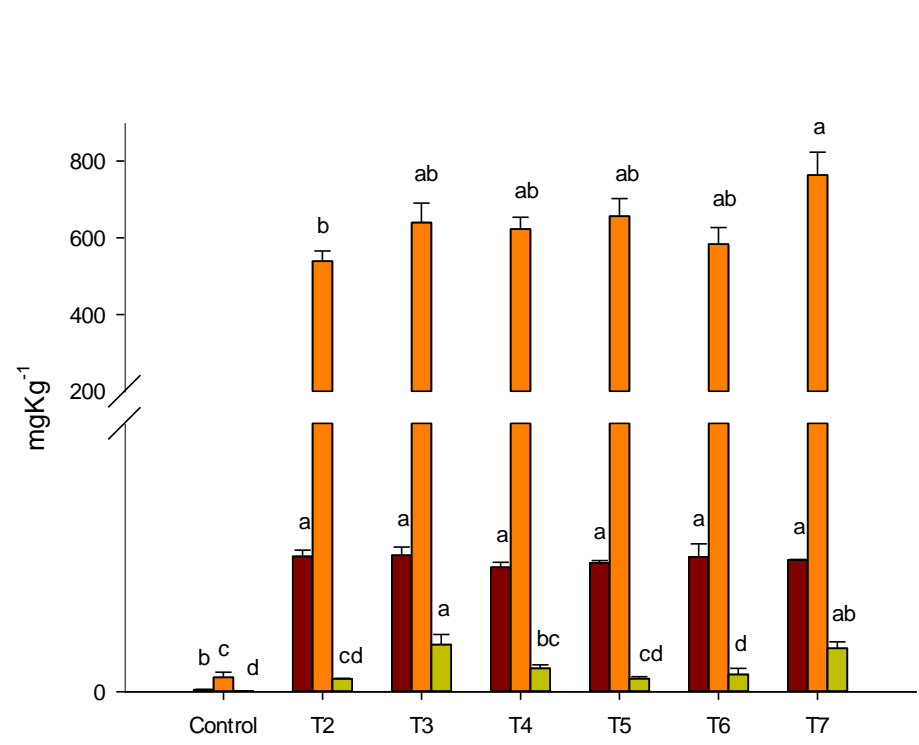

Fig 2. Total Hg concentration in different compartments (soil, root and leaf) after maize cultivation in soil that was contaminated with mercury and inoculated with different bacteria. Averages followed by the same letters do not differ statistically from each other by the Duncan test at the $5 \%$ probability level.

Table 2. Remediation potential of RED LATOSOL contaminated by mercury, with maize cultivation in association with different bacteria

\begin{tabular}{llll}
\hline Treatments & Accumulated in plant (\%) & Removed from soil (\%) & Removed by plant (\%) \\
\hline Positive control & $0.12 \mathrm{c}$ & $92.23 \mathrm{a}$ & $0.13 \mathrm{c}$ \\
Negative control & $6.19 \mathrm{~b}$ & $46.10 \mathrm{~b}$ & $13.78 \mathrm{~b}$ \\
Enterobacter cloacae & $7.21 \mathrm{ab}$ & $45.67 \mathrm{~b}$ & $15.84 \mathrm{ab}$ \\
Bacillus subtilis & $5.91 \mathrm{~b}$ & $50.46 \mathrm{~b}$ & $11.61 \mathrm{~b}$ \\
Enterobacter sp. & $7.62 \mathrm{ab}$ & $48.72 \mathrm{~b}$ & $15.67 \mathrm{ab}$ \\
Staphylococcus epidermidis & $6.63 \mathrm{~b}$ & $46.33 \mathrm{~b}$ & $14.94 \mathrm{ab}$ \\
Bacillus sp. & $9.34 \mathrm{a}$ & $47.54 \mathrm{~b}$ & $19.67 \mathrm{a}$ \\
\hline
\end{tabular}

Averages followed by the same letters, in columns, do not differ statistically from each other by the Duncan test at the $5 \%$ probability level.

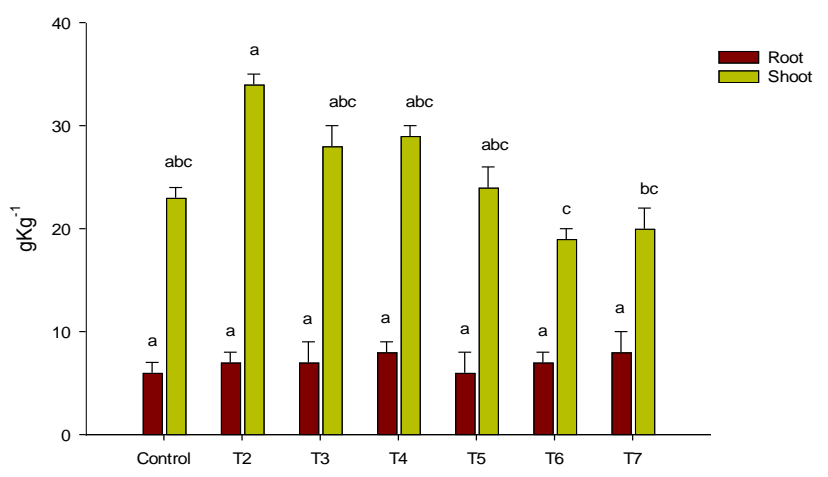

Figure 1. Root and shoot dry mass of maize plants grown in soil contaminated with mercury and inoculated with different bacteria. Averages followed by the same letters do not differ statistically from each other by the Duncan test at the $5 \%$ probability level. 
Table 3. Correlation of variables in maize.

\begin{tabular}{|c|c|c|c|c|c|}
\hline & Final soil pH & Root dry mass & $\begin{array}{l}\text { Shoot dry } \\
\text { mass }\end{array}$ & $\begin{array}{c}\text { Total root } \mathrm{Hg} \\
\text { content }\end{array}$ & $\begin{array}{c}\text { Total shoot Hg } \\
\text { content }\end{array}$ \\
\hline Final soil Hg content & $0.27 N S$ & $0.34 \mathrm{NS}$ & $0.05 \mathrm{NS}$ & $0.82 * *$ & $0.38^{*}$ \\
\hline Root Hg content & $0.14 N S$ & $0,16 \mathrm{NS}$ & $0.06 \mathrm{NS}$ & - & $0.46^{*}$ \\
\hline Shoot Hg content & $-0.12 N S$ & $-0.09 N S$ & $0.32 \mathrm{NS}$ & $0.46^{*}$ & _ \\
\hline
\end{tabular}

stems than in the grains, and this mechanism is a detoxification strategy of maize plants (Fu et al., 2014). The results of the mass balance (Table 2) showed a difference of 30 to $40 \%$ between the amount removed from the soil and the $\mathrm{Hg}$ stored in plants. Some plants can be considered phytovolatilizers, that is, they are able to absorb heavy metals, translocate them to shoots and volatilize them into the atmosphere (Tangahuet al., 2011). This process could therefore have favored the elimination of $\mathrm{Hg}$ initially present in the contaminated soil. Another hypothesis is that part of $\mathrm{Hg}$ has been lost by volatilization due to the reduction of $\mathrm{Hg}$ (II) to $\mathrm{Hg}^{0}$.

Leaching losses can be disregarded since the soil was stored in plastic bags to minimize these losses. After contaminating the soil with $\mathrm{HgCl}_{2}\left(2 \mathrm{mg} \mathrm{kg}^{-1} \mathrm{Hg}(\mathrm{II})\right)$ and incubating for 2 months, Wang et al. (2003) found that only $0.14 \%$ of the metal was in the form of $\mathrm{HgCl}_{2}, 11.25 \%$ was converted into $\mathrm{Hg}^{0}$ and the remainder to other forms. The gaseous form can be transferred from the soil to the atmosphere and then absorbed through the leaves via stomata.

The emission of $\mathrm{Hg}^{0}$ by soil depends on several factors (soil properties, temperature, and light radiation) (Magarelliet al., 2005; Carpiet al., 2014). In this way, we suggest that part of the $\mathrm{Hg}$ found in the shoots of plants is due to the volatilization of the soil $\mathrm{Hg}$.

$\mathrm{Hg}^{0}$ is predominantly found deposited in the vegetation of the Antarctic tundra, with higher deposition at the beginning of spring, when vegetation grows and accumulates $\mathrm{Hg}^{0}$ (Obristet al., 2017). The deposition of atmospheric $\mathrm{Hg}$ was also observed in the forests in the USA (Rischet al., 2017) and the Amazon region, which, due to their high leaf area and perennial characteristics, are able to trap atmospheric $\mathrm{Hg}$. The cycle repeats when leaves fall and $\mathrm{Hg}$ deposited in shoots returns to the soil to be absorbed again (Ericksen et al., 2003; Fostier et al., 2015).

Although some of the $\mathrm{Hg}$ present in soil can be volatilized, other processes favor its retention. In a reducing environment, it precipitates in the form of mercury sulfide (HgS) (Mahbubet al., 2017), which has less mobility and reactivity as a function of adsorption to iron sulfate and pyrite (Steinet et al., 1996).

$\mathrm{Hg}$ adsorption to clay and iron and aluminum oxides also limits its mobility. The clay fraction of soil favors the retention of metal ions on the soil surface since it is the most reactive fraction due to its greater specific surface area (Soares et al., 2015).

In soils contaminated with $\mathrm{Hg}$, as in Minamata Bay, Japan, Bacillus sp. was the microorganism most prevalent in sediments (Nakamura et al., 1988). This microorganism was also the most resistant in soil contaminated with $\mathrm{Hg}$ according to Figueiredo et al. (2016) and Purkan et al. (2017).

This bacterium has brown colonies with a circular outline, is gram-positive, and has the merA gene that is responsible for the detoxification mechanism by reducing $\mathrm{Hg}^{2+}$ into $\mathrm{Hg}^{0}$, a less toxic form of the metal. Mer genes act in the coding of proteins associated with the transportation, regulation, reduction and decomposition of $\mathrm{Hg}$ compounds (Matsui and Endo, 2018) as a strategy for the survival of bacteria in contaminated environments.

The mer gene of Bacillus sp. encodes the mercury reductase enzyme (Giriet al., 2014; Amin and Latif, 2016; Dash et al., 2017) and shows optimal activity at $\mathrm{pH} 6$ and $37^{\circ} \mathrm{C}$ (Purkan et al., 2017). These conditions are close to those of our study and the synergistic action of Bacillus sp. In addition, maize plants favor phytoremediation.

Several aerobic and anaerobic bacteria may exhibit resistance to heavy metals. Enterobacter cloacae previously isolated from soil contaminated with $\mathrm{Hg}$ (II) in the present study was also isolated by Amin and Latif (2016) and showed in vitro resistance to $\mathrm{Hg}$ in culture medium with $20 \mathrm{\mu g} \mathrm{mL}^{-1}$ of $\mathrm{HgCl}_{2}$. According to the authors, this bacterium has high nitrogen fixation potential, similar to Bacillus sp., and significant AIA production (auxin).

In addition, the growth potential of Enterobacter cloacae and Bacillus sp. in soil contaminated with and without $\mathrm{HgCl}_{2}$ and cultivated with Cicer arietinum L. (Amin and Latif, 2016) is known in the literature. The authors identified that the consortium inoculation of these bacteria resulted in increased germination of seeds, fresh root and shoot mass, and number of pods per plant when compared to control Hg-contaminated soil that did not receive bacteria.

In our study, it was observed that treatments inoculated separately with E. cloacae and Bacillus sp. showed faster germination than the control and treatment 2, suggesting that the use of these bacteria contributes to decreasing stress in maize plants grown in soils with high $\mathrm{Hg}$ concentrations. While there is no physical contact of roots with the soil, microorganisms are able to use molecular mechanisms to stimulate plant growth (Pérez-Floreset al., 2017) and to benefit the germination of treatments that were inoculated.

The literature has demonstrated the bioaccumulatory potential of Enterobacter sp. in reducing $\mathrm{Hg}^{2+}$ to $\mathrm{Hg}^{0}$ and accumulating $\mathrm{Hg}$ in the cytoplasm (Sinha and Khare, 2012; Sinha et al., 2013; Amin and Latif, 2017).

Microorganisms have adaptation mechanisms to survive under contamination conditions; for example, an $S$. epidermidis isolate from soil in the city of Lanzhou, China, showed high resistance to the presence of $\mathrm{Hg}$, with efficient $\mathrm{Hg}$ (II) reduction and the presence of the mer $A$ gene. This bacterium showed optimal growth at $37^{\circ} \mathrm{C}$ and $\mathrm{pH}$ from 5.6 to 8.5 (Yuet al., 2014); however, when used in the present study, S. epidermidis did not express its full bioremediation potential, as Bacillus subtilis did. In our study, the faster germination of treatments that were contaminated with $\mathrm{Hg}$ (II) and received weekly bacteria inoculations may have been favored by the fact that microorganisms transformed contaminants into less toxic forms, which benefited the germination process by lowering contamination stresses and favoring initial growth. 


\section{Plant materials}

\section{Isolation of bacteria}

The microorganisms used in the experiment were isolated from oxisol contaminated with $\mathrm{HgCl}_{2}$ solution at concentrations of 5,12 and $36 \mathrm{mg} \mathrm{kg}^{-1}$ of $\mathrm{Hg}$ (II) and cultivated with Kenaf (Hibiscus cannabinus) for 75 days in a parallel experiment. Of 180 microorganisms isolated from soil and plants, only 12 were grown in vitro in $\mathrm{BHI}$ cultivation medium with $54 \mathrm{mg} \mathrm{kg}^{-1}$ of $\mathrm{Hg}$ (II). Five microorganisms were chosen for the phytoremediation test of maize plants because they were easy to cultivate. DNA extraction from bacteria was performed by the adapted Kuramae-Izioka method (1997). Extracts were submitted to polymerase chain reaction (PCR) for $16 \mathrm{~S}$ amplification.

At the Laboratory of Genomics and Expression (LGE) of Unicamp, SP (Brazil), samples were sequenced (Sanger) with a protocol for the Hitachi $4500 \mathrm{ABI}$ and bioinformatics applications (Basecall, Alignment, Blastn) and identified as Enterobacter cloacae (95\%), Bacillus subtilis (93\%), Enterobacter spp. (96\%), Staphylococcus epidermidis (95\%) and Bacillus sp. (93\%).

\section{Experimental design}

The experimental design was completely randomized with a 7x4 scheme: T1: control, without the inoculation of bacteria and without the addition of $\mathrm{Hg}(\mathrm{II}) ; \mathrm{T} 2$ : addition of $36 \mathrm{mg} \mathrm{kg}^{-1}$ of $\mathrm{Hg}$ (II) no inoculation. T3: addition of $36 \mathrm{mg} \mathrm{kg}^{-1}$ of $\mathrm{Hg}$ (II) + inoculation with Enterobacter cloacae; T4: addition of 36 $\mathrm{mg} \mathrm{kg}^{-1}$ of $\mathrm{Hg}(\mathrm{II})+$ inoculation with Bacillus subtilis; $\mathrm{T5}$ : addition of $36 \mathrm{mg} \mathrm{kg}^{-1}$ of $\mathrm{Hg}(\mathrm{II})+$ inoculation with Enterobacter sp. and; T6: addition of $36 \mathrm{mg} \mathrm{kg}^{-1}$ of $\mathrm{Hg}$ (II) + inoculation with Staphylococcus epidermidis and; T7: addition of $36 \mathrm{mg} \mathrm{kg}^{-1}$ of $\mathrm{Hg}(\mathrm{II})+$ inoculation with Bacillus sp.

\section{Soil preparation}

An oxisol with no history of $\mathrm{Hg}$ contamination was collected in the $0-0.20 \mathrm{~m}$ layer in Jaboticabal, SP. The sample was dried in air and shade, sieved using a $2 \mathrm{~mm}$ sieve and sent for chemical analysis.

The results were $\mathrm{pH}\left(\mathrm{CaCl}_{2}\right)=5.5$, organic matter $=20 \mathrm{~g} \mathrm{dm}^{-}$ ${ }^{3}$, phosphorus $=22 \mathrm{mg} \mathrm{dm}^{-3}$, sulfur $=7 \mathrm{mg} \mathrm{dm}^{-3}$, calcium $=30$ $\mathrm{mmol}_{\mathrm{c}} \mathrm{dm}^{-3}$, magnesium $=12 \mathrm{mmol}_{\mathrm{c}} \mathrm{dm}^{-3}$, potassium $=4.0$ $\mathrm{mmol}_{\mathrm{c}} \mathrm{dm}^{-3}$, aluminum $=0 \mathrm{mmol}_{\mathrm{c}} \mathrm{dm}^{-3}$, potential acidity $(\mathrm{H}+\mathrm{Al})=19 \mathrm{mmol}_{\mathrm{c}} \mathrm{dm}^{-3}$, cation exchange capacity= $65 \mathrm{mmol}_{\mathrm{c}}$ $\mathrm{dm}^{-3}$, base-cation saturation $=71$, boron $=0.30 \mathrm{mg} \mathrm{dm}^{-3}$, copper $=4.6 \mathrm{mg} \mathrm{dm}^{-3}$, iron $=8 \mathrm{mg} \mathrm{dm}^{-3}$, manganese $=9.5 \mathrm{mg}$ $\mathrm{dm}^{-3}$, zinc $=2.5 \mathrm{mg} \mathrm{dm}^{-3}$ and total $\mathrm{Hg}=0.099 \mathrm{mg} \mathrm{kg}^{-1}$.

For 3 days, soil was autoclaved for 30 minutes at $121^{\circ} \mathrm{C}$ and $1 \mathrm{~atm}$. Dry soil was packed in pots with a capacity of $2 \mathrm{~kg}$ that were coated with plastic bags to avoid leaching losses.

Contamination was performed with manually homogenized solid $\mathrm{HgCl}_{2}$. Throughout the experiment, sterile deionized water was used at $70 \%$ of the soil field capacity.

After contamination, soil was fertilized according to Melo et al. (1998). The total $\mathrm{Hg}$ content of the fertilizers used in the experiment had values of $0.38 \mathrm{mg} \mathrm{kg}^{-1}$ of ammonium sulfate, $0.056 \mathrm{mg} \mathrm{kg}^{-1}$ of superphosphate and $0.008 \mathrm{mg} \mathrm{kg}^{-1}$ of potassium chloride.
On the $8^{\text {th }}$ day after soil contamination, samples were collected for $\mathrm{pH}$ determination. Then, maize seeds (2B710PW cultivar) were immersed for 10 minutes in sodium hypochlorite solution (10\%), washed with sterile distilled water, and placed in pots ( 5 units per pot). Sowing fertilization (Melo et al., 1998) and bacteria were immediately applied. Thinning was performed when plants reached $0.10 \mathrm{~m}$, maintaining only one plant per pot.

\section{Preparation and application of microorganisms in mercury- contaminated soil}

From a suspension of pure colonies that were individually cultured in $\mathrm{BHI}$, inoculums were prepared at a concentration of $6 \times 10^{8} \mathrm{CFU}$ (Vivas et al., 2006) according to the MacFarland scale and $1 \mathrm{~mL}$ of inoculum per pot was applied at 7-day intervals.

Collection of roots and shoots of maize plants and soil at the end of the experiment

Collection was performed 30 days after thinning. For the preparation of roots, all adhered soil was carefully removed, followed by washing with aqueous neutral detergent solution $\left(1 \mathrm{~mL} \mathrm{~L}^{-1}\right)$, running water, distilled water and deionized water.

Samples were oven dried at $67^{\circ} \mathrm{C}$ with forced air circulation until a constant weight was obtained, weighed to obtain dry phytomass, milled in a Willey mill with a 40 mesh sieve and stored in plastic bags.

The $2 \mathrm{~kg}$ of soil in each pot was sieved with a $5 \mathrm{~mm}$ mesh diameter. Then, an aliquot of $0.5 \mathrm{~kg}$ of each sample was collected and sent for quantification of total $\mathrm{Hg}$ and $\mathrm{pH}$ evaluation at the end of the experiment.

Mercury content in soil and plant samples

All samples were crushed in a mortar with the aid of liquid nitrogen to obtain a more homogeneous material and better analytical accuracy. The mercury content in solid samples was measured using the Direct Mercury Analyzer ${ }^{\circledR}$ (DMA-80 TRICELL; Milestone Inc., Italy). This method combines sample combustion (for thermal $\mathrm{Hg}$ reduction and vaporization) with atomic absorption spectroscopy (Melendez-Perez and Fostier, 2013).

Two analytical curves were constructed in linear ranges from 0.2 to $10 \mathrm{ng}$ of $\mathrm{Hg}$ and from 150 to $1,000 \mathrm{ng}$ of $\mathrm{Hg}$. For this purpose, $\mathrm{Hg}$ standard solutions $\left(10,100\right.$ and $\left.10,000 \mu \mathrm{g} \mathrm{L}^{-1}\right)$ were prepared by diluting $\mathrm{Hg}$ standard stock solution (1.000 $\pm 0.003 \mathrm{mg} \mathrm{mL}^{-1}, \mathrm{Tec}^{- \text {Lab }^{\circledR}}{ }^{\circ}$ Hexis, Jundiaí, Brazil) in deionized water with $10 \%$ subdistilled $\mathrm{HNO}_{3}$. The validation parameters of the analytical method included linearity and limit of quantification (LOQ). Accuracy was checked daily by analyzing standard reference materials of tomato leaves (SRM NIST 1573) and soil (Montana soil SRM NIST 2711). Accuracy was assessed by the relative standard deviation of all analytical SRM replicates. Each experimental sample was also analyzed in duplicate. For each replicate, samples weighing between 10 and $200 \mathrm{mg}$ were analyzed, depending on the expected concentration. 


\section{Validation of the analytical method}

The correlation coefficients of the 0.2 to $10 \mathrm{ng}$ and 150 to $1000 \mathrm{ng}$ calibration curves were 0.9941 and 0.9966 , respectively. The recovery percentages were 105 and 106\% for soil and SRM leaves, respectively. Accuracy (19 and 9 analytical replications performed on soil and SRM leaves, respectively) was lower than $4 \%$. The variation coefficient for samples analyzed in duplicate was $<10 \%$.

\section{Remediation efficiency}

The Hg remediation efficiency by plant according to the type of treatment was calculated based on mass balance data. For each pot in each treatment (Ti), the following parameters were considered (Table 1): $\mathrm{mmSi}$ : $\mathrm{Hg}$ mass present in the soil at the beginning of $\mathrm{Ti}(\mathrm{mg})=\mathrm{Hg}$ concentration in the soil at the beginning of $\mathrm{Ti}\left(\mathrm{mg} \mathrm{kg}^{-1}\right) \times 2$ $\mathrm{kg}$ (soil mass in the culture pot); $\mathrm{mmSf}: \mathrm{Hg}$ mass present in the soil at the end of $\mathrm{Ti}(\mathrm{mg})=\mathrm{Hg}$ concentration in the soil at the end of $\mathrm{Ti}\left(\mathrm{mg} \mathrm{kg}^{-1}\right) \times 2 \mathrm{~kg}$ (soil mass in the culture pot); $\mathrm{mmR}$ : $\mathrm{Hg}$ mass accumulated in the roots of $\mathrm{Ti}(\mathrm{mg})=\mathrm{Hg}$ concentration in the roots of $\mathrm{Ti}\left(\mathrm{mg} \mathrm{kg}^{-1}\right) \times$ root mass of $\mathrm{Ti}$ (kg); mmPA: Hg mass accumulated in the shoots of $\mathrm{Ti}(\mathrm{mg})=$ $\mathrm{Hg}$ concentration in the shoots of $\mathrm{Ti}\left(\mathrm{mg} \mathrm{kg}^{-1}\right) \times$ shoot mass of $\mathrm{Ti}(\mathrm{kg})$

From these, four other parameters were calculated: \% of accumulated $\mathrm{Hg}$ in plants treated with $\mathrm{Ti}=(\mathrm{mmR}+\mathrm{mmPA})$ $\mathrm{x} 100 / \mathrm{mm} \mathrm{Si}$; $\%$ of $\mathrm{Hg}$ recovered from soil in treatment $\mathrm{Ti}=$ (mmSi - mmSf) $\times 100 / \mathrm{mm} \mathrm{Si}$ : Direct contribution of the plant in the recovery of $\mathrm{Hg}$ from soil in treatment $\mathrm{Ti}=$ (mmR + mmPA) x100 / (mmSi-mmSf)

\section{Statistical analysis}

The results were submitted to statistical analysis using the AgroEstat software (2015), with Duncan's test for comparison between means at the $5 \%$ probability level.

\section{Conclusions}

Among the evaluated treatments, the association of maize plants with Bacillus sp. showed better performance in soil $\mathrm{Hg}$ recovery, with higher $\mathrm{Hg}$ remediation by the plant, and therefore can be considered a potential remediation agent of this metal. However, further studies are needed to identify potential long-term bioremediation options and the effects of their application on large contaminated areas.

\section{Acknowledgments}

We would like to thank Capes for scholarship Code 001.

\section{References}

Amin A, Latif Z (2017a) Cloning, expression, isotope labeling, and purification of transmembrane protein MerF from mercury resistant Enterobacter sp. AZ-15 for NMR studies. Front Microbiol. 8:1250.

Amin A \& Latif Z (2017b) Screening of mercury-resistant and indole-3-acetic acid producing bacterial-consortium for growth promotion of Cicer arietinum L. J Basic Microbiol. 57(3):204-217.

Atsdr (2011) Priority list of hazardous substances. Agen Toxic Subst Dis.
Bastos WR (2012) A contaminação por mercúrio na Bacia do Rio Madeira: uma breve revisão. Geoch Brasil. 18(2):99114.

Bastos WR, Gomes JPO, Oliveira RC, Almeida R, Nascimento EL, Bernardi JVE, de Lacerda LD, da Silveira EG \& Pfeiffer WC (2006) Mercury in the environment and riverside population in the Madeira River Basin, Amazon. Brazil Sci Total Environ. 368(1):344-351.

Beckers F \& Rinklebe J (2017) Cycling of mercury in the environment: Sources, fate, and human health implications: A review. Critic Rev Environ Sci Technol. 47(9):693-794.

Cabrita MT, Duarte B, Cesário R, Mendes R, Hintelmann H, Eckey K, Dimock B, Caçador I, Canário J (2019) Mercury mobility and effects in the salt-marsh plant Halimione portulacoides: uptake, transport, and toxicity and tolerance mechanisms. Sci Total Environ. 650:111-120.

Carpi A, Fostier AH, Orta OR, dos Santos JC, Gittings M (2014) Gaseous mercury emissions from soil following forest loss and land use changes: Field experiments in the United States and Brazil. Atmos Environ. 96:423-429.

Chauhan P, Mathur J (2018) Potential of Helianthus annuus for phytoremediation of multiple pollutants in the environment: A Review. J Biol Sci Med. 4(3):5-16.

Dash HR, Sahu M, Mallick B \& Das S (2017) Functional efficiency of MerA protein among diverse mercury resistant bacteria for efficient use in bioremediation of inorganic mercury. Biochimie. 142:207-215.

De Lacerda L (2003) Updating global Hg emissions from small-scale gold mining and assessing its environmental impacts. Environ Geol. 43(3):308-314.

de Melo W (1998) Experimentação sob condições controladas.

Debeljak M, van Elteren JT, Špruk A, Izmer A, Vanhaecke F \& Vogel-Mikuš K (2018) The role of arbuscular mycorrhiza in mercury and mineral nutrient uptake in maize. Chemosph. 212:1076-1084.

Debeljak M, van Elteren JT \& Vogel-Mikuš K (2013) Development of a 2D laser ablation inductively coupled plasma mass spectrometry mapping procedure for mercury in maize (Zea mays L.) root cross-sections. Analyt Chim Acta. 787:155-162.

Dixit R, Malaviya D, Pandiyan K, Singh UB, Sahu A, Shukla R, Singh BP, Rai JP, Sharma PK, Lade H (2015) Bioremediation of heavy metals from soil and aquatic environment: an overview of principles and criteria of fundamental processes. Sustain. 7(2):2189-2212.

Domy CA (2001) Trace Elements in Terrestrial Environments: Biogeochemistry. Bioavailability and Risks of Metals. 2nd ed., University of Georgia, USA.-46.

Ericksen J, Gustin M, Schorran D, Johnson D, Lindberg S \& Coleman J (2003) Accumulation of atmospheric mercury in forest foliage. Atmosph Environ. 37(12):1613-1622.

Figueiredo NL, Canário J, O'Driscoll NJ, Duarte A \& Carvalho C (2016) Aerobic Mercury-resistant bacteria alter Mercury speciation and retention in the Tagus Estuary (Portugal). Ecotox Environ Safe. 124:60-67.

Fostier AH, Melendez-Perez JJ \& Richter L (2015) Litter mercury deposition in the Amazonian rainforest. Environ Pollut. 206:605-610.

Fu Z, Li W, Zhang Q, Wang L, Zhang X, Song G, Fu Z, Ding D, Liu Z \& Tang J (2014) Quantitative trait loci for mercury accumulation in maize (Zea mays L.) identified using a RIL population. Plos One. 9(9). 
Giri S, Dash HR, Das S (2014) Mercury resistant bacterial population and characterization of Bacillus sp., isolated from sediment of solid waste discharged point of steel industry. National Academy Science Letters. 37(3):237243.

Kabata-Pendias A, Mukherjee AB (2007) Trace elements from soil to human. Springer Science \& Business Media.

Kodre A, Arčon I, Debeljak M, Potisek M, Likar M, VogelMikuš K (2017) Arbuscular mycorrhizal fungi alter $\mathrm{Hg}$ root uptake and ligand environment as studied by X-ray absorption fine structure. Environ Exp Bot. 133:12-23.

Kumar B, Smita K \& Flores LC (2017) Plant mediated detoxification of mercury and lead. Arab J Chem. 10:S2335-S2342.

Kuramae-Izioka EE (1997) A rapid, easy and high yield protocol for total genomic DNA isolation of Colletotrichum gloeosporioides and Fusarium oxysporum. Revista Unimar. 19(3):683-689.

Leterme $B$, Jacques $D$ (2015) A reactive transport model for mercury fate in contaminated soil-sensitivity analysis. Environ Sci Pollut Res. 22(21):16830-16842.

Li P, Feng X, Qiu G, Shang L \& Li Z (2009) Mercury pollution in Asia: a review of the contaminated sites. J Hazard Mater. 168(2-3):591-601.

Magarelli G, Fostier AH (2005) Influence of deforestation on the mercury air/soil exchange in the Negro River Basin, Amazon. Atmosph Environ. 39(39):7518-7528.

Mahbub KR, Bahar MM, Labbate M, Krishnan K, Andrews S, Naidu R \& Megharaj M (2017) Bioremediation of mercury: not properly exploited in contaminated soils! Appl. Microbiol Biotechnol. 101(3):963-976.

Matsui K, Endo G (2018) Mercury bioremediation by mercury resistance transposon-mediated in situ molecular breeding. Appl. Microbiol. Biotechnol. 102(7):3037-3048.

Melendez-Perez JJ, Fostier AH (2013) Assessment of Direct Mercury Analyzer ${ }^{\circledR}$ to quantify mercury in soils and leaf samples. J Braz Chem Soc. 24(11):1880-1886.

Naguib MM, El-Gendy AO, Khairalla AS (2018) Microbial diversity of mer operon genes and their potential rules in mercury bioremediation and resistance. Open Biotechnol J. 12(1)

Nakamura K, Fujisaki T \& Shibata Y (1988) Mercury-resistant bacteria in the sediment of Minamata bay [Japan]. Bull Japan Soc Sci Fish (Japan).

Obrist D, Agnan Y, Jiskra M, Olson CL, Colegrove DP, Hueber J, Moore CW, Sonke JE, Helmig D (2017) Tundra uptake of atmospheric elemental mercury drives Arctic mercury pollution. Nature. 547(7662):201-204.

Pacyna JM, Travnikov O, Simone Fd, Hedgecock IM, Sundseth K, Pacyna EG, Steenhuisen F, Pirrone N, Munthe J, Kindbom K (2016) Current and future levels of mercury atmospheric pollution on a global scale.

Pedron F, Petruzzelli G, Barbafieri M, Tassi E (2013) Remediation of a mercury-contaminated industrial soil using bioavailable contaminant stripping. Pedosph. 23(1):104-110.

Pérez-Flores $\mathrm{P}$, Valencia-Cantero $\mathrm{E}$, Altamirano-Hernández J, Pelagio-Flores R, López-Bucio J, García-Juárez P, MacíasRodríguez L (2017) Bacillus methylotrophicus M4-96 isolated from maize (Zea mays) rhizoplane increases growth and auxin content in Arabidopsis thaliana via emission of volatiles. Protopl. 254(6):2201-2213.

Purkan P, Nuzulla YF, Hadi S, Prasetyawati ET (2017) Biochemical Properties of Mercuric Reductase from Local Isolate of Bacillus sp for Bioremediation Agent. Molekul. 12(2):182-188.

Qian X, Wu Y, Zhou H, Xu X, Xu Z, Shang L, Qiu G (2018) Total mercury and methylmercury accumulation in wild plants grown at wastelands composed of mine tailings: Insights into potential candidates for phytoremediation. Environ Pollut. 239:757-767

Risch MR, DeWild JF, Gay DA, Zhang L, Boyer EW, Krabbenhoft DP (2017) Atmospheric mercury deposition to forests in the eastern USA. Environ Pollut. 228:8-18.

Sinha A \& Khare SK (2012) Mercury bioremediation by mercury accumulating Enterobacter sp. cells and its alginate immobilized application. Biodegrad. 23(1):25-34.

Sinha A, Kumar S \& Khare SK (2013) Biochemical basis of mercury remediation and bioaccumulation by Enterobacter sp. EMB21. Appl Biochem Biotechnol. 169(1):256-267.

Soares LC, Linhares LA, Egreja Filho FB, Windmoller CC \& Yoshida MI (2015) Mercury content in soils of southeastern brazil without anthropogenic influence and its correlation with soil characteristics. Rev Brasil Cien Solo. 39(3):903-914.

Stein ED, Cohen Y, Winer AM (1996) Environmental distribution and transformation of mercury compounds. Critical reviews in Environ Sci Technol. 26(1):1-43.

Sundseth K, Pacyna JM, Pacyna EG, Pirrone N, Thorne RJ (2017) Global sources and pathways of mercury in the context of human health. Intern JEnviron Res Public Health. 14(1):105.

UNEP GMA (2002) United Nations Environment Programme. Chemicals, Geneva, Switzerland.

Vivas A, Biro B, Németh T, Barea J, Azcón R (2006) Nickeltolerant Brevibacillus brevis and arbuscular mycorrhizal fungus can reduce metal acquisition and nickel toxicity effects in plant growing in nickel supplemented soil. Soil Biol Biochem. 38(9):2694-2704.

Wagner-Döbler I (2013) Bioremediation of Mercury. Caister Academic Press, Norfolk, UK.

Wang D, Shi X, Wei S (2003) Accumulation and transformation of atmospheric mercury in soil. Sci. Total Environ. 304(1-3):209-214.

Windmöller $C C$, Júnior WAD, de Oliveira $A$, do Valle $C M$ (2015) The redox processes in Hg-contaminated soils from Descoberto (Minas Gerais, Brazil): implications for the mercury cycle. Ecotox. Environ. Safe. 112:201-211

Xun Y, Feng L, Li Y \& Dong H (2017) Mercury accumulation plant Cyrtomium macrophyllum and its potential for phytoremediation of mercury polluted sites. Chemosph. 189:161-170

Yu Z, Li J, Li Y, Wang Q, Zhai X, Wu G, Liu P, Li X (2014) A mer operon confers mercury reduction in a Staphylococcus epidermidis strain isolated from Lanzhou reach of the Yellow River. International Biodeter Biodegrad. 90:57-63.

Zeng $F$, Ali S, Zhang $H$, Ouyang $Y$, Qiu B, Wu F, Zhang G (2011) The influence of $\mathrm{pH}$ and organic matter content in paddy soil on heavy metal availability and their uptake by rice plants. Environ Pollut. 159(1):84-91 